\title{
EARTHQUAKE HAZARDS OF GRAND TETON NATIONAL PARK EMPHASIZING THE TETON FAULT
}

\author{
R.B. Smith
}

and

\author{
J.O.D. Byrd
}

Department of Geology and Geophysics

University of Utah

salt Lake city

\section{Objectives}

This is a progress report on the research of the University of Utah project: "Earthquake Hazards of The Grand Teton National Park Emphasizing The Teton Fault", to date, 31 December, 1989. The research objectives during 1989 focussed on: 1) excavation of a trench across the Teton fault to determine the age and amount of displacement associated with prehistoric ground breaking earthquakes; 2) collection of paleomagnetic samples of Huckleberry Ridge tuff along an E-W transect across the northern end of the Teton range to assess deformation associated with the Teton fault; 3) mapping and surveying of two study areas along the fault to evaluate the geomorphic expression of the fault; 4) surveying a detailed topographic and gravity profile across the valley from string Lake to the Snake River to evaluate deformation of the valley floor and to help constrain modeling of the subsurface fault geometry, 5) continuing the study of expected fault motion of the Teton fault based on our previous results, 6) mapping of the northern extent of the Teton fault zone, and 7) assisting the NPS with interpretations and use of our data for management and interpretational purposes.

In an allied research project, the 1st-order level-line, established across the Teton fault and adjacent valley as a part of this study in 1988, was resurveyed to evaluate the stability of the bench marks and to monitor any movement that may have occurred in the one year period since the initial survey. Note that the original level line was established in 1988 with UW-National Park Service support while the 1989 leveling effort was funded by the U.S. Geological Survey. 
Results

I. Excavation of the Teton Fault at Granite Canyon:

Excavation of trenches across active faults can provide information on the recent activity, ages of movement, and recurrence intervals of earthquakes on the fault that is not exposed at the surface. A $3 \mathrm{~m}$ high fault scarp at the mouth of Granite Canyon was excavated in september and october, 1989, to acquire the above data on the southern segment on the Teton fault. Trenching of the scarp exposed a $4.1 \mathrm{~m}$, down to the east, net tectonic displacement associated with a single event (Figure 1). Back tilt of the units in the hanging wall, downthrown block, is approximately 3 degrees to the west, whereas the depositional tilt in the upper units exposed in the footwall block is 2 degrees to the east. Removing these components of tilt yields a net vertical displacement of $4 \mathrm{~m}$.

Comparison of the displacement event recorded in Granite Canyon trench with the surface displacements associated with other earthquakes of the western U.S. Cordillera suggests that the displacement was produced by a $7.1<$ Ms $<7.5$ earthquake, and is the first quantitative estimate of the expected size for large and damaging earthquakes that could occur on the Teton fault in the future.

The faulting juxtaposed fluvial and debris flow deposits against a Pinedale age, approximately 15,000 year old, glacial till unit (Figure 1). Colluvial materials derived from the fault scarp have buried a fluvial unit capped by a paleosol horizon exposed in the downthrown block within the trench. The paleosol is characterized by a mottled olive gray-green to reddish brown, massive clay silt matrix with abundant pieces of charcoal up to $0.5 \mathrm{~m}$ in length and $4 \mathrm{~cm}$ diameter that were resting on the now buried upper surface of the soil horizon. Charcoal fragments were also observed at the base of the paleosol horizon. The charcoal fragments and mottled character of the paleosol are interpreted to be the product of a forest fire which burned through the area of the trench shortly before the faulting event. Carbon dating of these charcoal fragments is in progress and will provide a minimum age for the prehistoric earthquake.

A team of associated geologists with expertise in fault trenching and geology of the Teton region assisted us with the trenching project and critically reviewed the final results during a one-day visit in october, prior to closing of the trench. These included: Dean Ostenna and Jerry Gilbert (U.S. 
Figure 1: Stratigraphic log of the Granite Canyon trench across the Teton fault: Net tectonic displacement of $4.1 \mathrm{~m}$ calculated from extrapolation of upper contacts of Unit $\mathrm{E}$, in the footwall and hanging wall, into the Teton fault plane. Stratigraphic units: A: Pinedale glacial till; $B$ and $C:$ Fluvial/Debris flow deposits; D: Debris flow deposit; E: Fining upward fluvial deposit, exposed in footwall and hanging wall blocks; F: Paleosol; G: Colluvial wedge derived from fault scarp; $\mathrm{H}$ : Pebbley alluvial fan deposit; I: Upper colluvial wedge, sandy; $\mathrm{J}$ : Cobble-rich alluvial fan deposit; K: Colluvium. 


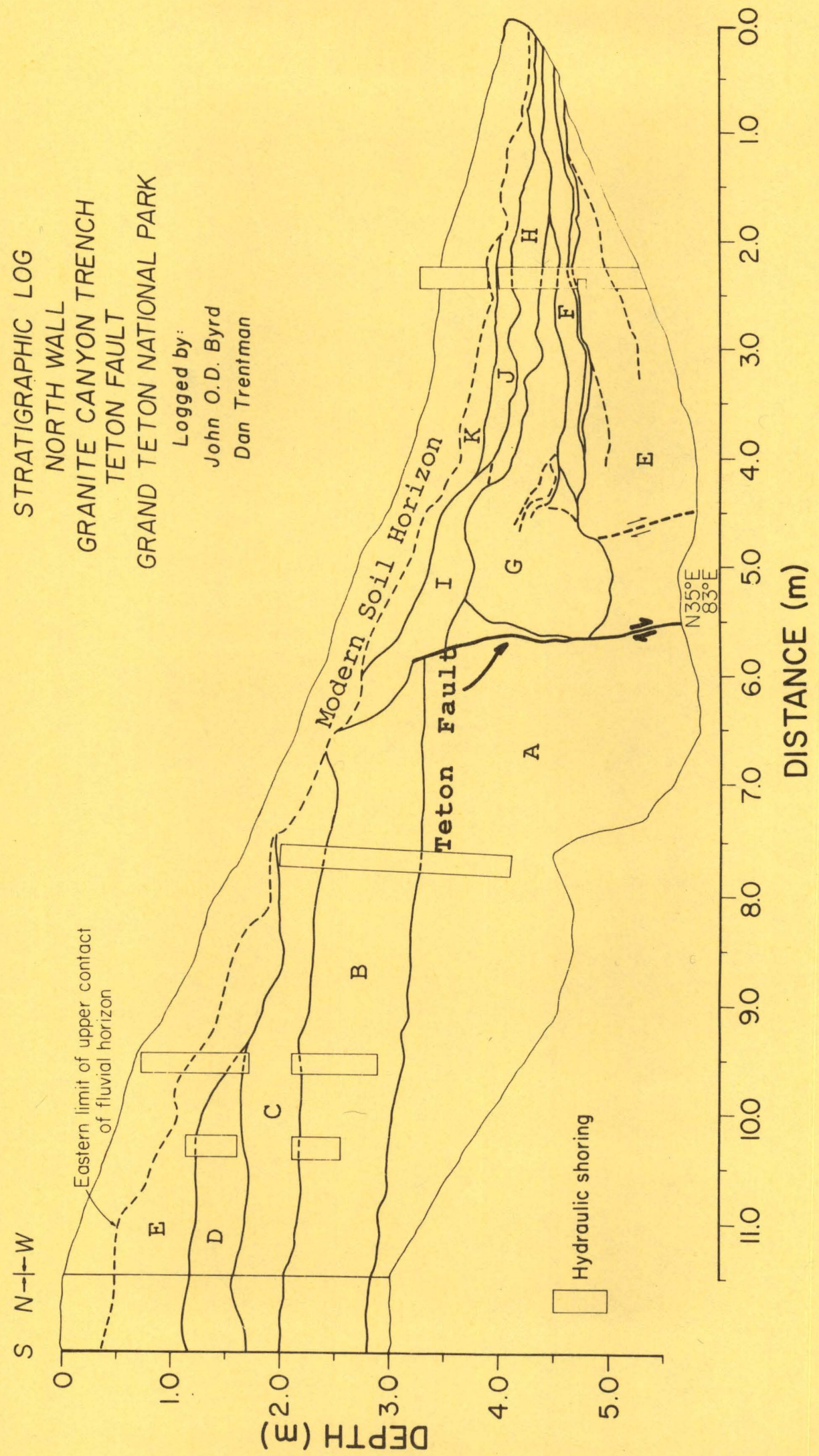


Bureau of Reclamation), Dave Love (USGS, retired), Bill Lund (Utah Geological and Mineralogical Survey), Jim McCalpin (Utah State University), Ron Bruhn (University of Utah), and Ken Pierce (USGS, Denver). The trench site was also visited by Marshall Gingery (Assistant superintendent, GTNP), George Menkens (UW-NPS Research Center), members of the GTNP interpretative staff, and John Goode (NPS, retired). An international visitor; vladimir Khromovskikh (Institute of the Earth's Crust, Irkutsk, USSR) also visited the site.

II. Paleomagnetic Study:

Paleomagnetic analysis of oriented and dated rock samples in the footwall and hanging wall of a fault is used to assess the amount of tilt and rotation of crustal blocks that may be related to movements associated with paleo-earthquakes. As a continuation of our 1988 paleomagnetic study, paleomagnetic samples were collected samples at 24 new sites in the 2.0 million year old Huckleberry Ridge Tuff along an E-W transect across the north end of the Teton Range (Figure 2). We continued our collaboration with Dr. John Geissman, University of New Mexico on this portion of the study, and also received logistical assistance from the National Park Service in this study.

Samples from 40 of the 69 paleomagnetic sites collected in 1988 and 1989 were analyzed in Dr. Geissman's laboratory in November and December, 1989. Preliminary results from these analyses suggest that at several locations that the westward tilt of the Huckleberry Ridge Tuff may be entirely due to vertical movement on the Teton fault. In addition, several of the sites in the steamboat Mountain area and at the east end of Berry Creek appear to have rotated about a vertical axis implying that a significant component of lateral shear has occurred along the northern end of the Teton fault zone. Statistical analyses of these data, along with analyses of the remaining samples, is continuing.

\section{Detailed Topographic Surveys and Gravity Profiling:}

Two areas adjacent to the Teton fault at Jenny Lake and Granite Canyon were surveyed using an electronic distance measuring device (EDM). This project collected topographic data for the purpose of evaluating the amount of lateral displacement across the fault, the geomorphic expression of the fault trace, determining the optimum location to excavate the fault, and to further constrain modeling of the surface deformation and subsurface geometry of the Teton fault. In addition, a detailed topographic and gravity profile was 
Figure 2: Distribution of paleomagnetic sampling sites throughout the Teton region. 


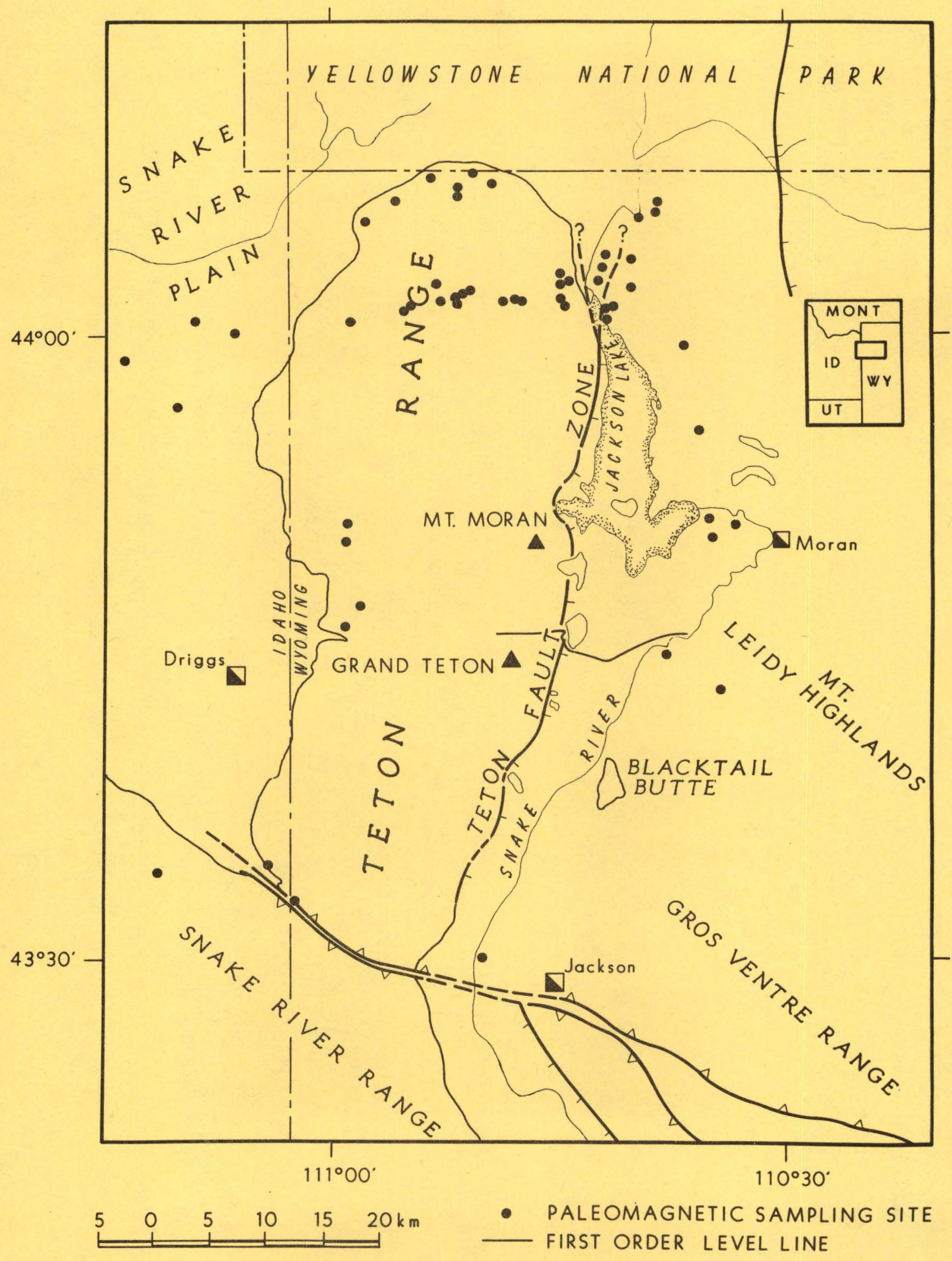


surveyed across the valley floor from string lake to the Snake River at approximately $500 \mathrm{~m}$ intervals. These data are currently being analyzed.

IV. Fault Mapping of Northern Teton Fault:

John Byrd also worked with geologists of the U.S. Bureau of Reclamation in mapping the northern segment extent of the Teton fault, northward from coulter Canyon to Wilcox Point. Mapping in these areas indicates that the main trace of the Teton fault is obscured in several areas by large landslides in bedrock and surficial materials. However, several traces of the fault were recognized suggesting that fault consists of a zone of deformation where displacement is may be distributed on to a number of different fault splays. In addition, investigations in the steamboat Mountain and GTNP/Yellowstone Park boundary areas along the Snake River channel suggests the existence of several faults that are interpreted as eastern splays of the Teton fault.

V. Survey of Cascade Canyon to Deadman Bar Level Line:

The 1989 resurvey of the 42 benchmark, $22.5 \mathrm{~km}$ long 1st-order level lines, established in 1988 with UW-NPS funding, was made in cooperation with Dr. Arthur Sylvester of the University of California-Santa Barbara and was funded in 1989 by the U.S. Geological Survey. The results of that survey show that the footwall block of the central segment of the Teton fault, subsided $5 \pm 0.7 \mathrm{~mm}$ during 1988 and 1989 , relative to a point about $10 \mathrm{~km}$ east of the fault. The precision for each survey was about one part in $5 \times 10^{-} 7$ and the maximum precision for each leveled segment is less than $1 \times 10^{-} 6$. The change in height occurred across a $1200 \mathrm{~m}$ wide zone that coincides with the steep escarpment at the base of the range front near Jenny Lake and includes the surface trace of the Teton fault with up to $25 \mathrm{~m}$ of Quaternary displacement at this location. In addition to relative subsidence of the mountain block, part of the valley (hanging wall block) immediately east of the fault rose about $2.0 \mathrm{~mm}$ across a $5 \mathrm{~km}$ wide zone, resulting in a total height difference of $6.5 \mathrm{~mm}$ across the fault.

Modeling of the 1988-1989 height changes suggests that the observed height variations may be due to variable reverse slip at depth on a planar, east dipping fault. Although the footwall height decrease may be local and unique to the Teton fault, perhaps due to interaction with structures in the seismically active Gros Ventre range $15 \mathrm{~km}$ to the east, this unexpected observation of aseismic, reverse displacement 
across a large, active normal fault raises a number of questions regarding deformation during interseismic periods. We consider a hypothetical model in which the Teton normal fault may be weakly locked in regional, east-west horizontal compression resulting in minor contraction across the fault in the interseismic interval. However, local changes in the state of stress leading to extension across the fault may give rise to coseismic deformation. Thereby resulting in a significant local contribution to the overall regional neotectonic pattern of east-west extension over geologic time scales.

\section{Conclusions}

our research in 1989 provided the first definitive data necessary to determine the amount of displacement and age of the most recent ground-breaking earthquake on the southern segment of the Teton fault with implications for the magnitude and displacement expected in future large earthquakes. Paleomagnetic data on the last 2 million years of deformation on the Teton fault, and a detailed topographic/gravity profile across the valley floor have also been acquired. Because of the late autumn completion of these field projects, data from these projects is currently being analyzed and will be available by the time of the grant completion.

\section{Presentation of Results:}

Earthquake hazards of the Teton fault and Jackson Hole area was the topic of a presentation to federal, state, and county officials given by R.B. Smith at the Teton Science School Lecture Series in February, 1989. In addition, R.B. Smith also participated in the Teton Science Schools "Future of Jackson Hole Symposium", in August, 1989 where he led a field trip for local officials along the Teton fault and discussed the earthquake hazards of the Teton region. 